\title{
Contribution of Recent Transgenic Models and Transcriptional Profiling Studies to Our Understanding of the Mechanisms by which Androgens Control Spermatogenesis
}

\author{
G. Verhoeven ${ }^{1, *}$, E. Denolet ${ }^{1}$, J.V. Swinnen ${ }^{1}$, A. Willems ${ }^{1}$, F. Claessens ${ }^{2}$, P.T.K. Saunders ${ }^{3}$, R.M. Sharpe ${ }^{3}$ and \\ K. De Gendt ${ }^{1}$
}

\begin{abstract}
${ }^{1}$ Laboratory for Experimental Medicine and Endocrinology and ${ }^{2}$ Molecular Endocrinology Laboratory, Catholic University of Leuven, Leuven, Belgium, and ${ }^{3}$ Medical Research Council Human Reproductive Sciences Unit, Centre for Reproductive Biology, Edinburgh, Scotland, UK
\end{abstract}

\begin{abstract}
Androgens play a key role in the control of spermatogenesis and interference with their intratesticular secretion and action is a critical element in many contraceptive strategies. Nonetheless, the cellular and molecular mechanisms by which androgens control germ cell development remain poorly understood. Recent transgenic models in which the androgen receptor (AR) is selectively ablated in Sertoli cells show unambiguously that the Sertoli cell is the main target for androgen action in the control of spermatogenesis. A number of additional mouse models have been developed mimicking human diseases in which mutations of the AR cause disturbed fertility without affecting male development. Transcriptional profiling studies in mice with Sertoli cell-selective AR ablation and in some other experimental paradigms have tried to identify androgen-regulated genes relevant to the control of spermatogenesis. The overlap in genes identified in different studies is poor but this may be due mainly to dissimilarities in experimental setup. In all studies, relatively large numbers of genes rather than a few key genes seem to be affected by androgen action. Genes related to tubular restructuring, cell junction dynamics, cytoskeleton, solute transportation and vitamin A metabolism are prominently present. Although further work is obviously needed, it may be anticipated that these studies will result in the identification of subsets of genes that can be used as diagnostic tools as well as in the identification of targets for the development of novel contraceptives.
\end{abstract}

Key Words: Testis, androgen receptor, cell-selective knockout, microarray, Sertoli cell.

\section{INTRODUCTION}

The pituitary gonadotropins FSH and LH control both the onset and maintenance of spermatogenesis and male reproductive function [1-3]. Their secretion is tightly controlled by central regulators such as hypothalamic GnRH and by testicular feedback signals including the steroid hormones testosterone and $17 \beta$-estradiol and the peptide hormone inhibin B. Most efforts to develop pharmacological methods of male contraception have aimed at manipulating gonadotropin secretion with consequent suppression of intratesticular testosterone levels [4-6]. These efforts have now provided a firm base to develop an acceptable male contraceptive, but it is obvious that further improvements are needed and that alternative approaches should be considered. Progress in this area will critically depend on a better understanding of the cellular and molecular mechanisms by which gonadotropins, and especially testosterone, secreted by the Leydig cells under the influence of LH, control spermatogenesis. Such an understanding may: 1) help to explain the important inter-racial and inter-individual variability in the efficiency of presently available male contraceptive protocols that rely on suppression of intratesticular testosterone; 2) point to key events in the control of germ cell development that may represent novel targets for pharmacological interference and 3) help to develop compounds that more selectively interfere with testicular targets of androgen action. In this review we will focus on recent progress in our understanding of the mechanisms by which testicular androgens affect spermatogenesis.

\section{ANDROGENS ARE KEY REGULATORS IN THE CON- TROL OF SPERMATOGENESIS}

There is an overwhelming amount of evidence showing that optimal spermatogenesis requires both $\mathrm{LH}$ and FSH. The relative role of these gonadotropins, however, may vary from species to

\footnotetext{
*Address correspondence to this author at the LEGENDO, Onderwijs en Navorsing 1, Gasthuisberg, Herestraat 49, bus 902, 3000 Leuven, Belgium; Tel: +32-16-34-59-73; Fax: +32-16-34-59-34;

E-Mail: guido.verhoeven@med.kuleuven.be
}

species and may differ whether initiation, maintenance or reinitiation of spermatogenesis is considered [1-3].

FSH affects spermatogenesis via the Sertoli cells which are widely accepted to be the only cells in the testis endowed with FSH receptors $[7,8]$. FSH plays a very important role in pre- and peripubertal Sertoli cell proliferation [9] and in this way it is a key determinant of spermatogenic capacity in adult life [2, 10]. Furthermore it has important effects on the proliferation and differentiation of spermatogonia and on the process of spermiation [11-13]. In general, FSH may play a more prominent role in primates and in man than in rats and mice [1-3].

LH acts on the Leydig cells to increase the secretion of testosterone. This results in the high intratesticular concentrations of testosterone that are apparently required to initiate and maintain spermatogenesis [2]. The circulating levels of testosterone are about 20-100 times lower than those measured in the testis but are obviously adequate for male sexual differentiation, stimulation of accessory sex glands, sexual behavior and hypothalamo-pituitary feedback. Testosterone plays a key role in the control of spermatogenesis. Only a few years after the discovery of the role of the pituitary in the maintenance of spermatogenesis [14] and of the distinct functions of LH and FSH [15] it was already shown that high amounts of exogenous androgens were able to substitute at least in part for the pituitary gland and to maintain qualitatively normal spermatogenesis in hypophysectomized mice [16] and monkeys [17]. Since then the ability of testosterone to initiate, maintain, or reinitiate spermatogenesis in the absence or in the virtual absence of FSH has been confirmed in a variety of species and by the use of a whole spectrum of experimental paradigms including intact and hypophysectomized animals, animals treated with GnRH agonists or antagonists, with FSH antisera or with the Leydig cell toxicant ethane dimethane sulphonate (for review [2]).

A number of recent genetic models nicely confirm the unique ability of testosterone to support some degree of spermatogenesis on its own. In mice that are hypogonadal due to a large deletion in the GnRH gene ( $h p g$ mice), for instance, administration of testosterone restores qualitatively complete spermatogenesis [18, 19]. 
Conversely, fertility is maintained in man and mice with inactivating mutations of the FSH receptor gene [20-22] and in mice that are unable to synthesize FSH $\beta$ [23].

A vast amount of experimental work has been done to define the exact stages at which androgens, alone or in collaboration with $\mathrm{FSH}$, affect germ cell development. In rodents a series of events centered about stage VII and VIII of the spermatogenic cycle seem particularly sensitive to hormonal disruption [2, 24-26]. Interestingly (see further) these are also the stages at which the concentration of the AR in Sertoli cells reaches maximal levels [27, 28]. Processes that are particularly sensitive to androgen action are Sertoli cell adherence of round spermatids, which is essential for further development into elongated spermatids [2, 3, 29-33], and spermiation $[12,34,35]$. Also progression through meiosis strictly depends on androgen action (see below). Surprisingly, high concentrations of androgens negatively affect spermatogonial differentiation in specific models in which only the early steps of spermatogenesis are present, such as irradiated rats or jsd mice at normal scrotal temperature $[36,37]$.

\section{ANDROGEN SIGNALING VIA CLASSICAL AND AL- TERNATIVE PATHWAYS}

The cellular and molecular mechanisms involved in the control of spermatogenesis by androgens remain poorly understood. Androgens are steroid hormones and their actions are largely mediated by a "classical" or genomic pathway shared by all steroid hormones. Central to this pathway is a specific receptor, the androgen receptor (AR), a member of the large family of ligand-activated nuclear receptors. The AR is encoded by a single gene, 75-90 kb long and located on the long arm of the $\mathrm{X}$ chromosome [38, 39]. The $110-\mathrm{kDa}$ AR protein displays a modular structure resembling that of other steroid receptors and characterized by: an aminoterminal domain involved in transcription activation, a central DNAbinding domain featuring two zinc-fingers, a hinge region and a carboxyterminal domain responsible for ligand recognition and, via interaction with the aminoterminal domain, also for transcription activation. A specific feature of the aminoterminal domain of the human AR is the presence of a CAG/polyglutamine repeat of variable length (average: $21 \pm 2$ ) that affects its inherent biological activity [40,41]. Although the data are somewhat controversial there are several indications that higher repeat lengths may lower androgen responsiveness, decrease sperm concentrations and increase effectiveness of hormonal contraception in men in which gonadotropin suppression is incomplete (for review [42]). Very large repeat lengths $(>37)$ result in a slowly progressive neurodegenerative disease characterized by flaccid proximal paralysis and muscle atrophy (spinobulbar muscular atrophy (SBMA) or Kennedy's disease) and also by signs of androgen insensitivity such as gynecomastia and progressive infertility [43]. The disease is probably caused by the formation of toxic complexes of the mutated AR allele with other proteins [44].

A detailed discussion of the mechanism(s) of androgen action is beyond the scope of the present review. We will only summarize the major events in the AR signaling cascade and mention some aspects that are either typical for androgen action and/or specifically relevant to the process of spermatogenesis. Activation of the AR occurs classically by the binding of natural ligands (testosterone, $5 \alpha$-dihydrotestosterone) or synthetic ligands with agonistic effects. This activation is followed by nuclear translocation, increased phosphorylation and subsequent interaction of the AR as a homodimer with specific recognition sequences known as AREs (Androgen Response Elements) [38, 39, 45, 46]. These AREs are located in the regulatory regions of androgen-responsive genes. Their structure shows an important degree of variability. "Classical" AREs are inverted partial repeats of 5'-TGTTCT-3'-like sequences separated by 3 nucleotides. They act not only as ARE but also as GRE and PRE (Glucocorticoid/Progesterone Response Ele- ment). Apart from these classical promiscuous AREs, however, there also exist "selective" AREs that do not recognize the GR. They are organized as direct rather than inverted repeats of 5'TGTTCT-3'-like sequences and display an alternative binding mode to the AR [47]. Binding of the AR to the DNA ultimately results in the recruitment of coactivators, corepressors and other regulatory molecules or mediators which induce structural alterations in the chromatin and facilitate direct and indirect interactions with the transcription initiation complex $[48,49]$. Both the nature of the AREs and the nature of the coregulatory molecules are important determinants of the spectrum of genes that is ultimately activated or inactivated. A specific coactivator known as transcription intermediary factor 2 (TIF-2) may serve as the preferential coactivator of the AR in testicular Sertoli cells $[50,51]$.

A specific feature of androgen action is the important role played by so called "active metabolites". At least two active metabolites complement the spectrum of effects induced by the main circulating androgen: testosterone. In a variety of target tissues $5 \alpha$ reduction of testosterone results in the formation of $5 \alpha$-dihydrotestosterone (DHT) a more potent androgen that binds to the same AR $[52,53]$. This conversion may be catalyzed by one of two distinct $5 \alpha$-reductases (referred to as type 1 and type 2) [54]. Some androgen effects depend entirely on the ability of particular target tissues to produce DHT, as illustrated by a specific form of male pseudohermaphroditism observed in patients with an absence of the $5 \alpha$ reductase, type 2 and characterized by normal internal male genital structures and defective external virilisation [55]. Alternatively, testosterone may be converted by aromatization into $17 \beta$-estradiol. which will then act via its cognate receptors the estrogen receptors $\alpha$ or $\beta$ (ER $\alpha$ and $E R \beta)$ [52, 56]. Again, animals and patients with defective aromatase activity or absence of one of the ERs illustrate the essential role played by this active metabolite for some of the actions of testosterone on bone and on fertility [57].

Apart from these classical "genomic" pathways there probably exist "alternative" signaling pathways that may or may not involve the classical AR and that may explain some specific and/or extremely rapid effects [58]. Testosterone has been shown for instance to induce rapid increases in intracellular calcium in isolated Sertoli cells. These effects are counteracted by the anti-androgen hydroxyflutamide suggesting involvement of the AR [59]. Similarly, evidence has been presented that testosterone activates mitogen-activated protein kinase (MAPK) and cAMP response elementbinding protein (CREB) via Src kinase and the epidermal growth factor receptor in Sertoli cells, an action that may involve a population of AR localized to the plasma membrane $[60,61]$. The physiological role of these alternative signaling pathways is poorly understood but certainly merits further investigation, given the fact that quantitatively normal spermatogenesis seems to require concentrations of androgens higher than those required to saturate the AR.

\section{FUNDAMENTAL QUESTIONS ABOUT ANDROGEN AC- TION IN THE TESTIS REMAIN UNANSWERED}

There is an overwhelming amount of data showing that defects in testicular androgen production, whether occurring spontaneously, or induced (for instance by contraceptive methods involving the administration of androgens and/or progestagens) disturb fertility [4-6, 42]. There is also increasing evidence that defects in androgen signaling may have major effects on germ cell production $[38,42]$. In some of the latter defects, the disturbed fertility is due to major derangements in sexual differentiation and/or aberrant location of the testis. In others, however, including some specific point mutations of the AR, infertility is the main or only clinical feature [38, 42]. Despite all this, we are still far away from a detailed understanding of how androgens act in the testis. Several fundamental questions remain unanswered: 1) What is the relative contribution of various testicular cells to the control of spermatogenesis? 2) Why does normal spermatogenesis apparently require concentrations of 
androgens that are higher than those needed to saturate the AR? 3) What is the role of active metabolites such as DHT and 17 $\beta$ estradiol? 4) What are the molecular pathways via which androgens control germ cell proliferation and development?

Here we will focus on the identification of the cells responsible for the control of spermatogenesis by androgens and particularly on some recently developed transgenic models that are relevant to this question and that may aid in identification of the molecular pathways involved.

\section{IDENTIFICATION OF THE SERTOLI CELL AS THE MAIN TARGET FOR ANDROGEN ACTION IN THE CON- TROL OF SPERMATOGENESIS}

It is unlikely that germ cells themselves serve as a direct target for androgen action in the testis. Though not all studies consent [62], one recent study suggests that fetal germ cells express the AR and are targets for androgens that physiologically inhibit their proliferation [63]. Most studies agree that adult germ cells do not express the AR [28, 64]. Furthermore, expression of the AR in germ cells is apparently not required for germ cell development. Germ cells in which the AR is defective develop normally when they are supported by AR-positive Sertoli cells $[65,66]$ and mice with a germ cell specific AR knockout display normal fertility [67]. The only possibility that cannot be excluded is that androgens might affect germ cells via one of the mentioned alternative pathways that do not involve the AR.

The main AR-positive cells in the testis are somatic cells such as Sertoli cells, peritubular myoid cells and Leydig cells [28, 68, 69]. Given their intimate morphological and functional interactions with developing germ cells, Sertoli cells are generally considered prime candidates as mediators of androgen effects on spermatogenesis.

\subsection{The In Vitro Approach: Isolated and Cultured Sertoli Cells}

Despite the fact that isolated and cultured Sertoli cells express the AR, attempts to study androgen action in such cultures have yielded rather disappointing results. Only a limited number of genes, proteins or activities have been identified that are allegedly regulated by androgens in primary cultures of Sertoli cells (Table 1) [4]. Moreover, the amplitude of the observed effects is limited and for some of the effects doubt has been raised about the nature of the underlying mechanisms [70]. Part of the stimulatory effects of androgens on ABP production and secretion for instance may be related to ligand-induced protein stabilization [71]. Similarly, the stimulatory effects of androgens on Sertoli cell transferrin secretion $[72,73]$ and the inhibitory effects on FSH-induced aromatase activity [74] may largely be mediated by androgen-controlled paracrine factors - usually referred to as P-Mod-S (Peritubular factors that Modulate Sertoli cell function) - secreted by contaminating peritubular myoid cells [75-78]. A number of additional androgenregulated proteins produced by Sertoli cells have been identified by anion exchange high-performance liquid chromatography or 2D-gel electrophoresis [79-81] but most of them are low abundance proteins and/or have not been studied in more detail.

Studies with immortalized Sertoli cell lines have been equally disappointing [82]. The widely used TM4 line was originally reported to be AR-positive but has proven of little help in the identification of androgen-regulated genes with the possible exception of a $78 \mathrm{kD}$ glucose-regulated protein [83]. Similarly, in MSC-1 cells induction of the androgen-responsive Rhox 5 gene (see below) could be demonstrated but only after cotransfection with an AR expression construct [84]. An SK11 cell line which has recently been shown to be AR-positive and capable of driving an ARE reporter gene [85] may hold promise for further investigation.

The fact that primary cultures of Sertoli cells and Sertoli cell lines have been of limited help in the identification of genes affected by androgen signaling can probably be explained by a relatively important loss of differentiated function. This loss of function is nicely illustrated by the failure of these cells to express Rhox5 (Reproductive homeobox on the $\mathrm{X}$ chromosome 5, earlier referred to as Pem). Rhox 5 is a homeobox gene, specifically expressed in Sertoli cells and epididymal cells in vivo $[84,86]$ and widely used as a lead gene in the search for androgen effects on Sertoli cells. In vivo its expression is stimulated up to 50 -fold by androgens during the development of the mouse testis [86]. In isolated Sertoli cells, however, Rhox 5 expression drops to undetectable levels within the first 24 hours of culture [87]. A specific feature of this loss of differentiated function may be a reduction in androgen responsiveness. Although cultured Sertoli cells express measurable levels of AR $[69,71]$, attempts to demonstrate androgen responsiveness by use

Table 1. Genes, Proteins or Activities Regulated by Androgens in Isolated Sertoli Cells

\begin{tabular}{|c|c|c|c|c|}
\hline Parameter & Assay & Response & Species & References \\
\hline Androgen Binding Protein (ABP) & protein & $\uparrow$ & rat & {$[71,72,115,142]$} \\
\hline Transferrin & protein + mRNA & $\uparrow$ & rat & {$[72,73]$} \\
\hline Testibumin (CMB-1) & protein & $\uparrow$ & rat & [143] \\
\hline Testins (CMB22, CMB23) & protein & $\uparrow$ & rat & [144] \\
\hline N-Cadherin & protein & $\uparrow$ & rat & {$[145,146]^{*}$} \\
\hline FSH-induced aromatase & activity & $\downarrow$ & rat & [74] \\
\hline Plasminogen activator & activity & $\downarrow$ & rat & [147] \\
\hline Glutathion S-transferase $\alpha$ & protein + mRNA & $\uparrow$ & pig & [148] \\
\hline UDP-glucuronosyl transferase 1 A1 \& B1 & mRNA & $\uparrow$ & rat & [149] \\
\hline c-Myc & mRNA & $\uparrow$ & rat & {$[150]$} \\
\hline Claudin 11 & $\begin{array}{c}\text { mRNA } \\
\text { protein+mRNA }\end{array}$ & $\begin{array}{l}\uparrow \\
\uparrow\end{array}$ & $\begin{array}{c}\text { mouse } \\
\text { rat }\end{array}$ & $\begin{array}{l}{[151]} \\
{[152]}\end{array}$ \\
\hline Ornithine decarboxylase & protein+mRNA & $\downarrow$ & rat & [153] \\
\hline TGF- $\beta 1$ & mRNA & $\downarrow$ & pig & [154] \\
\hline
\end{tabular}

*only in the presence of FSH and in immature Sertoli cells 
of transfected androgen-responsive promoter-reporter constructs have yielded equivocal results. In one study with low transfection efficiency, induction mediated by the endogenous AR could be demonstrated [88]. In a subsequent study with a much higher transfection efficiency no induction was seen for three different promoter-reporter constructs even after doubling of the endogenous AR concentration by pretreatment with FSH [89]. In the latter study marked induction was observed, however, after cotransfection with an $\mathrm{AR}$ expression construct suggesting that $\mathrm{AR}$ concentration is a limiting factor. In fact, several data indicate that androgen responsiveness of Sertoli cells may vary considerably depending on their specific environment and may be modulated not only by hormones including androgens themselves and FSH [71], but also by paracrine factors such as P-Mod-S [62, 75, 90] and by signals generated by the associated complement of germ cells $[62,91]$. The latter point is illustrated by the marked changes in AR concentration during the cycle of spermatogenesis and the fact that the highest concentrations of AR are noted at those stages (stage VII and VIII) that are also most dependent on androgen action [27, 28]. It is tempting to speculate that in a system where the AR may be continuously saturated by the high local concentrations of testosterone, variations in AR concentration and androgen responsiveness may be an important way to allow modulation of androgen action.

\subsection{The In Vivo Approach: Sertoli Cell-Selective Knockout of the AR}

The described findings point to the need to study androgen action in Sertoli cells under conditions that preserve their microenvironment including their interactions with surrounding testicular cells. Mice in which the AR is selectively ablated in Sertoli cells offer an experimental paradigm that may meet these requirements.

Cell-selective knockouts can be generated by a technology (Cre/LoxP) that exploits the ability of the Cre recombinase (derived from bacteriophage P1) to mediate efficient site-specific recombination between $34 \mathrm{bp}$ recognition sites known as loxP sites [92]. The use of this technology depends upon the development of two transgenic mouse strains: one in which a critical region of the targeted gene (e.g. the AR) is "floxed" (by insertion of a loxP site at its 5'-upstream and its 3'-downstream end) and one that expresses the Cre recombinase in a cell-selective fashion (or ubiquitously). When both loxP sites are oriented in the same direction, the Cre recombinase will remove the floxed region, when the sites are in opposite orientation it will invert the floxed region. At present three transgenic models with a Sertoli cell-selective knockout of the AR have been developed (Fig. 1 A-C) [68, 93, 94]. We will discuss in some detail the SCARKO (Sertoli Cell-selective AR KnockOut) model developed in our laboratory and compare its phenotype with that of the two other Sertoli cell-selective knockouts: the S-AR ${ }^{-1 y}$ mouse and the $\mathrm{Ar}^{\text {flox(ex1-neo)/Y}} ;$ AMH-Cre mouse.

\subsubsection{The SCARKO Model}

SCARKO mice were produced by crossing females carrying an $\mathrm{AR}$ allele with a floxed exon $2\left(\mathrm{AR}^{\text {flox }}\right.$ ) with males expressing the Cre recombinase under the control of the Anti-Müllerian Hormone promoter (AMH-Cre) [68]. Exon 2 encodes the crucial first zinc finger of the AR DNA-binding domain and its deletion provokes a frame shift and premature termination of the AR transcript [95]. The AMH-Cre construct drives expression of the Cre recombinase selectively in Sertoli cells from day 15 postcoitum onwards [96]. For comparative purposes mice with a ubiquitous AR knockout (ARKO) were also produced by crossing the same $\mathrm{AR}^{\text {flox }}$ females with males expressing the Cre recombinase ubiquitously from early zygote stage onwards under control of the phosphoglycerate kinase promoter [97]. Table 2 summarizes the main features of the SCARKO mouse and compares them with those of the ARKO, the $\mathrm{AR}^{\text {flox }}$ and those of another mouse model expressing a mutated AR and to be discussed later: the SPARKI.
Since the construction of a floxed AR modifies the wild-type AR gene it is essential to show that these modifications as such do not affect AR function. Table 2 confirms that this is the case for the $\mathrm{AR}^{\text {flox }}$ developed in our laboratory. Testis weight at day 50 is slightly decreased but this difference is not noted at day 140 (data not shown) and all other parameters studied are normal. The phenotype of the ARKO reflects a complete androgen insensitivity syndrome and confirms that the Cre/loxP system is working properly. ARKO males are undistinguishable from normal female littermates and show a female growth curve. Their testes are very small and located intra-abdominally. Wolffian duct derivatives such as epididymides, deferent ducts and seminal vesicles are absent. Spermatogenesis is severely disturbed but the cryptorchid position of the testes obscures the contribution of defective androgen action in the observed defect. LH production is markedly increased reflecting both defective Leydig cell function [98] and disturbed androgenmediated negative feedback. The ARKO phenotype is essentially identical to that of mice with a spontaneous inactivation of the AR (Tfm mice) [99] and to that of mice with ubiquitous excisions of the AR exon 1 [93, 100], exon 2 [101] or exon 3 [102], generated in other laboratories.

SCARKO mice show a completely different and unique phenotype. They are undistinguishable from wild-type males, have normally developed internal male genital tracts and show a male growth curve. The testes are normally descended in the scrotum and are larger than those of the ARKO, but are still markedly reduced in size in adulthood ( $28 \%$ of wild-type). Immunohistochemistry confirms complete absence of AR staining in Sertoli cells whereas staining in Leydig cells and peritubular cells is nicely preserved. Absence of a functional AR selectively in Sertoli cells is further confirmed by quantitative RT-PCR as well as immunohistochemistry showing absence of Rhox 5 mRNA and protein expression in Sertoli cells whereas expression in the epididymis is preserved.

Stereological analysis reveals that the number of Sertoli cells (as estimated from Sertoli cell nuclear volume) is identical in SCARKO and control testes [103]. This is in contrast to animals with a ubiquitous ablation of the AR [100] which show a progressive decline in the number of Sertoli cells from day 2 onwards [103-105]. Since this decrease can apparently not be explained by the intra-abdominal location of the testes [104], these findings suggest that androgens affect Sertoli cell number during early development by a pathway that does not involve the Sertoli cell AR. It is tempting to speculate that androgen signaling via peritubular myoid cells may be responsible. Along the same lines, some key developmental processes in Sertoli cells such as the prepubertal decline in AMH expression, the acute increase in the expression of $\mathrm{p} 27^{\mathrm{kip} 1}$ and GATA1 at around the time of Sertoli cell maturation and the progressive increase in sulphated glycoprotein 2 with maturation, all seem to proceed normally in the SCARKO and even in the ARKO testis [103], suggesting their non-dependence-on a functional Sertoli cell AR .

Despite all this, Sertoli cells in the SCARKO testis are obviously functionally defective and unable to support spermatogenesis. Concordant with the reduction in testicular volume there is a marked decrease in tubular diameter and in tubular lumen size probably reflecting a defect in secretory function, a process known to be dependent on androgen action [106]. Moreover, stereological analysis reveals that the number of spermatogonia is preserved in the SCARKO testis but that the number of spermatocytes, round spermatids and elongated spermatids is reduced to $64 \%, 3 \%$ and $0 \%$ of wild-type respectively $[68,103]$. This apparent block in meiosis is confirmed by the reduced expression of typical meiotic genes such as SCP-3 and Spo-11 and the absence of expression of postmeiotic genes such as transition proteins and protamines. The absence of round spermatids cannot be explained by premature sloughing from the epithelium, as no round spermatids are observed 
A.

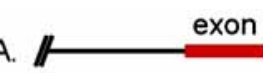
exon 2

B.

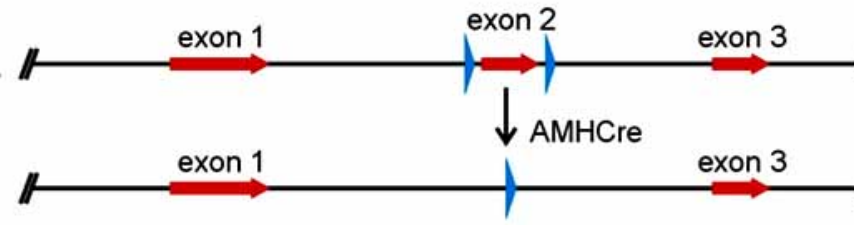

c.
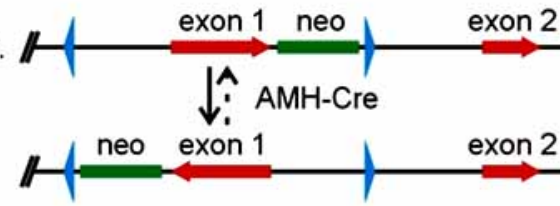

$\rightarrow$

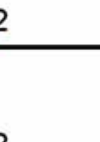

exon 2
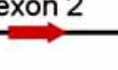

2

D.
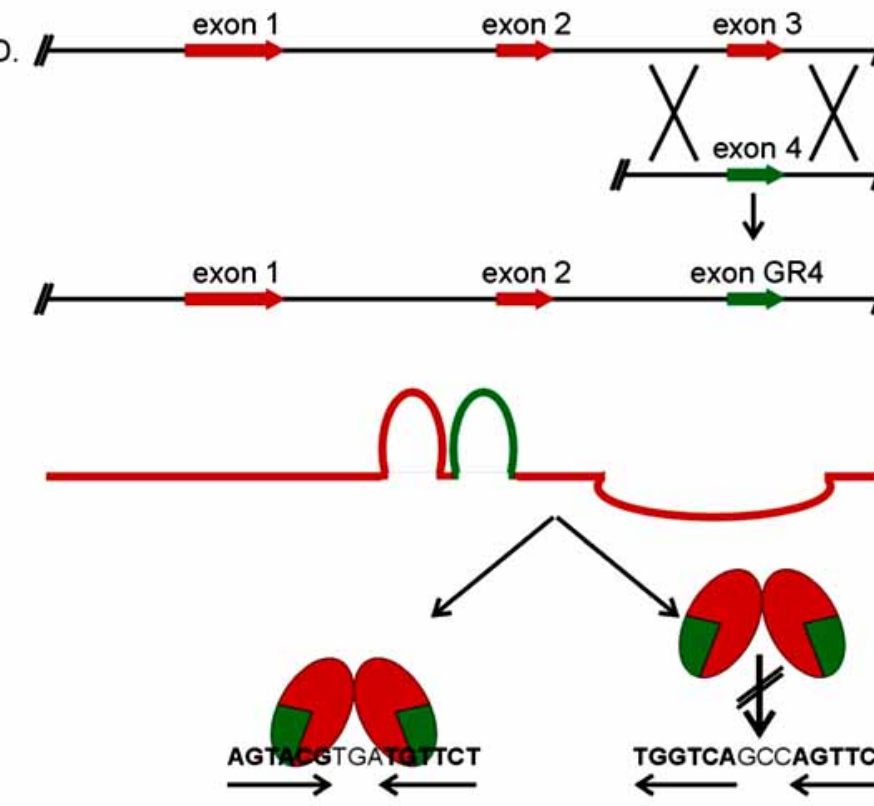

Classical ARE exon 3

exon 3

exon 3

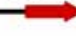

WT AR allele

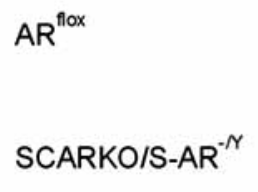

$\operatorname{Ar}^{\text {flox(ex1-neo) }}$
$A r^{\text {flox(ex1-neo)r }} ; A M H-C r e$

AR allele

GR allele

SPARKI allele

SPARKI protein

Fig. (1). Schematic representation of discussed mutant androgen receptor (AR) alleles. A. The first 3 exons (red arrows) of the wild-type AR (WT AR allele). B. AR with a floxed exon $2\left(\mathrm{AR}^{\mathrm{flox}}\right)$. The loxP sites (blue arrowheads) are oriented in the same direction. Female mice carrying the $\mathrm{AR}^{\text {flox }}$ are crossed with male mice expressing the Cre recombinase selectively in Sertoli cells under control of the Anti-Müllerian Hormone promoter (AMH-Cre) to generate male mice with a Sertoli cell-selective AR knockout (SCARKO or S-AR ${ }^{-1 y}$ ) by excision of the AR exon 2. C. AR allele in which exon 1 is floxed by 2 loxP sites oriented in opposite direction $\left(\mathrm{Ar}^{\text {flox(exl-neo) }}\right)$. A neomycin selection cassette (neo) in intron 1, used in the generation of mice carrying the allele is not removed. The crossing of female mice carrying the $\mathrm{Ar}^{\text {flox(exl-neo) }}$ allele with male AMH-Cre mice generates males in which the AR is selectively inactivated in Sertoli cells by inversion of the floxed exon 1 ( $\mathrm{Ar}^{\text {flox(ex1-neo)/Y}}$; AMH-Cre). D. Homologous recombination of exon 3 of the WT AR with exon 4 of the GR results in an AR allele in which the region encoding the second zinc-finger of the DNA-binding domain of the AR is replaced by the corresponding region of the GR. This SPARKI allele (Specificity-Affecting AR KnockIn) encodes an AR that is still able to bind classical (non-selective) AREs but is no longer able to bind and activate genes driven by a selective ARE.

in the epididymis, but is apparently due to a 5-fold increase in the number of apoptotic germ cells [68].

Interestingly, selective ablation of the AR in Sertoli cells also affects Leydig cell development and function. In the adult SCARKO testis the number of Leydig cells is reduced by about $50 \%$ but Leydig cell volume is increased by $25 \%$ and expression of steroidogenic enzymes is also increased [107]. Seminal vesicle weight and serum testosterone levels are undistinguishable from those of control littermates and LH levels tend to be slightly increased although not statistically significant.

\subsubsection{Other Sertoli Cell-Selective Knockouts}

Two other Sertoli-cell selective knockout models have been reported. The first one $\left(\mathrm{S}-\mathrm{AR}^{-/ \mathrm{y}}\right)$ also relies on the excision of the AR exon 2 and uses the same AMH-Cre expressing mouse strain utilized in the development of the SCARKO (Fig. 1B) [94]. The 
phenotype of these animals strongly resembles that of the SCARKO. The main difference is apparently that S-AR ${ }^{-/ y}$ males show hypotestosteronemia and a 4.5-fold increase in LH levels. This slightly different phenotype can probably be explained by minor technical differences and/or differences in genetic background. Considerably more important discrepancies are observed with the second model in which exon 1 is the targeted region of the $\mathrm{AR}$ and in which this exon is floxed by two loxP sites oriented in opposite direction (Fig. 1C) [93]. In this case the floxed males (Arflox(ex1-neo)/Y ) already display reduced AR levels and a hypomorphic phenotype due to the presence of a neomycine selection cassette in the first intron of the floxed AR allele. The hypomorphic animals have reduced testis weights ( $81 \%$ of the control), disturbances in the late stages of spermatid differentiation near the time of spermiation, and a reduction in epididymal sperm numbers to $3.9 \%$ of normal. LH and testosterone levels are increased 23-fold and 40-fold respectively. Crossing of this floxed strain with an AMH-Cre expressing strain (distinct from the one used in the two other models) results in an inversion of exon 1 selectively in Sertoli cells and a further reduction of epididymal sperm numbers to $0.9 \%$. The Sertoli cell-selective knockout of the AR in this model $\left(\mathrm{Ar}^{\text {flox(ex1-neo)/Y}}\right.$; AMH-Cre) is apparently not as complete as in the SCARKO or the $\mathrm{S}-\mathrm{AR}^{-/ y}$ as judged by the higher testicular weight ( $60 \%$ of wild-type vs. $29 \%$ ) and the nature of the spermatogenic defect which is situated at the level of the transition of round to elongating spermatids rather than at the level of meiosis. One explanation might be that Cre-induced inversion is in principle a reversible reaction.

\subsubsection{Lessons from Sertoli Cell-Selective Knockout Models}

The main lesson from all three Sertoli cell-selective AR knockout models is that they demonstrate, for the first time unambiguously, that the Sertoli cell is the key target of androgen action in the control of spermatogenesis. Moreover, both the SCARKO and the $\mathrm{S}-\mathrm{AR}^{-/ y}$ suggest that - at least as far as progression through meiosis is concerned - the classical AR is the main mediator involved and that alternative signaling pathways bypassing this receptor play no or only a minor role. In fact, the defect in germ cell development observed in the SCARKO and the S-AR ${ }^{-1 /}$ is as severe, or even more severe, than the defect observed in a number of models in which testosterone levels in the testis are drastically reduced such as rats treated with silastic implants releasing low doses of testosterone and estradiol [3] or mice in which the gene encoding the $\beta$ subunit of LH [108] or the gene encoding the LH receptor [109111] is inactivated. Finally, both the SCARKO and the S-AR model stress that progression through meiosis is critically dependent on androgen action. Recent research has mainly emphasized conversion of round into elongated spermatids [2, 3, 29-33] and spermiation $[12,34,35]$ as targets that are particularly sensitive to androgen action. Effects of androgens on meiotic progression have been observed, however, in many models in which gonadotropins were reduced to undetectable levels by hypophysectomy, or by pharmacological means [112-114], or in which LH [108] or the LH receptor [109-111] were more specifically inactivated. In most of these models spermatogenesis proceeds to the pachytene spematocyte level and administration of androgens induces completion of meiosis and formation of spermatids. A particularly relevant model is the hpg mouse in which spermatogenesis is also arrested at the pachytene spermatocyte stage and in which treatment with testosterone restores qualitatively normal spermatogenesis and fertility in the absence of measurable levels of FSH $[18,19]$. Detailed doseresponse studies in this model reveal that progression through meiosis requires doses of testosterone that are lower than those needed to allow conversion of round into elongated spermatids [18]. The observation that spermatid development rather than progression through meiosis is affected in the $\mathrm{Ar}^{\text {flox(ex1-neo)/Y}}$; AMH-Cre model is also compatible with the hypothesis that lower levels of androgen action may be sufficient to allow completion of meiosis.
The Sertoli cell-selective knockout models also indicate that some effects of androgens on the testis do not depend on the Sertoli cell AR. It is apparent for instance that the Sertoli cell AR is not required for normal testicular descent in the scrotum. Along the same lines and as discussed above, the effect of androgens on the proliferation of Sertoli cells does not require an active AR in Sertoli cells and may be mediated via neighbouring androgen target cells such as the peritubular myoid cells. Gene expression studies suggest that also other Sertoli cell activities such as expression of transferrin mRNA may depend at least in part on such an indirect pathway [103]. The contention that peritubular myoid cells may modulate or even mediate some effects of androgens on Sertoli cells and spermatogenesis is supported not only by in vitro data mentioned earlier $[75,76,78,90,115]$ but also by the recent demonstration that animals with a knockout of the AR in peritubular cells display a reduction in testis size and oligozoöspermia [116]. Some caution may be needed in the interpretation of the data on this peritubular AR knockout, however, since the construct used to target Cre expression to peritubular myoid cells has also been shown to induce Cre expression in other cells such as vascular smooth muscle cells [117].

Finally, the SCARKO model also yields some interesting information with respect to Leydig cell development. Earlier experiments have demonstrated that the development of the adult generation of Leydig cells is completely blocked in mice with a ubiquitous inactivation of the AR $[98,100,107]$. SCARKO mice develop adult Leydig cells as shown by the normal or even increased expression of typical markers such as insulin-like factor-3 and estrogen sulfotransferase. Nonetheless, a decrease in the number of Leydig cells is evident from day 20 onwards. Functionally, this decrease seems to be largely compensated by Leydig cell hyperplasia [107]. Taken together these data suggest that Leydig cell development not only requires direct actions of androgens on developing Leydig cells [98, 118] but also indirect signals most likely mediated by androgenregulated paracrine factors derived from Sertoli cells. These observations are reminiscent of earlier in vitro $[119,120]$ and in vivo experiments [121, 122] showing that FSH also stimulates Leydig cell development via paracrine agonists secreted by Sertoli cells. The nature of the paracrine mediators responsible for LeydigSertoli cell interaction remains uncertain. The hypotestosteronemia observed in the S-AR ${ }^{-/ y}$ model has been related to increased expression of AMH which is known to inhibit the development of the adult Leydig cell generation and steroidogenesis [123, 124]. In the SCARKO model, however, AMH expression is not increased and shows the expected age-related decline [103]. The marked decrease in the expression of PDGF-A in the SCARKO testis [107], a growth factor known to be involved in Leydig cell development [125], suggests that this might be one of the factors involved.

\section{OTHER TRANSGENIC MODELS WITH MUTANT AR ALLELES AFFECTING SERTOLI CELL DEVELOPMENT AND FUNCTION}

As described above, natural variations in the length of the CAG/polyglutamine repeat in the amino-terminal part of the human AR may affect AR activity, fertility and responsiveness to contraceptive treatment [42]. Moreover, pathological expansion of the length of this repeat (>37) causes a motor neuron disease (SBMA) also accompanied by signs of androgen insensitivity, reduced fertility and testicular atrophy [43]. Two transgenic mouse models have been developed that shed some more light on the testicular effects of these increased repeat lengths. In the first model a full length human AR carrying 120 CAG repeats was over-expressed ubiquitously [126]. A decrease in daily sperm production was observed in the presence of normal levels of testosterone, LH and FSH. The defect was suggested to be due to a toxic gain of function of the mutated protein rather than to a loss of function since such a loss would likely have been corrected for by the endogenous mouse AR. 
In the second study, a knockin mouse model was developed in which a 113 CAG repeat was inserted in the mouse AR [127]. The mutant AR allele resulted in a progressive disturbance of germ cell maturation, decreased testis weight and infertility from the age of 10 weeks onwards. Immunostaining for $\beta$-tubulin revealed marked disturbances in the Sertoli cell cytoskeleton coinciding with or preceding the development of the testicular pathology. Quantitative RT-PCR for different marker genes of germ cell development indicated a diminished ability of Sertoli cells to support postmeiotic germ cells rather than a complete block in meiosis as observed in Tfm mice. A partial androgen insensitivity syndrome was suggested by the combination of normal testosterone levels and markedly increased LH levels as well as by the decreased production of male urinary proteins (MUP), a family of androgen-regulated pheromone binding proteins produced by the liver. The fact that testicular Rhox 5/Pem expression in the knockin was as high as in the wildtype, however, and the decreased solubility of the mutant AR in protein lysates of the testis again suggest that the disturbances in Sertoli cell function reflect a toxic effect related to the expanded glutamine repeat rather than to a loss of function of the AR.

Some mutations in the AR gene have been shown to cause spermatogenic disturbances without altering the phenotype or external genitalia of the affected infertile men, and even without causing changes in $\mathrm{LH}$ and testosterone levels, suggesting that such mutations interfere with specific downstream actions that affect spermatogenesis but not LH secretion [42]. A similar dissociation of AR downstream effects is observed in the recently described SPARKI (Specificity-affecting AR KnockIn) mouse model [128].

The SPARKI mouse was developed to test whether classical AREs (that are unable to distinguish between the AR and the GR) and selective AREs (that supposedly only recognize the AR) activate different subsets of genes in vivo as they seem to do in vitro [47]. To this end the wild-type AR was replaced by a mutant allele in which the second zinc-finger is replaced by the second zincfinger of the GR resulting in a chimaeric protein that retains the ability to bind classical AREs but is unable to bind selective AREs (Fig. 1D). SPARKI mice display a unique phenotype reflecting a form of androgen insensitivity that is not only partial but also selective (Table 2). Males carrying the SPARKI allele show normal male development and differentiation and their growth curve coincides with that of normal males, suggesting that selective AREs are not essential for the anabolic effects of androgens. Whereas testosterone and LH levels are markedly increased in $\mathrm{Ar}^{\text {flox(ex1-neo)/Y }}$ mice [93], a model of partial androgen insensitivity due to a ubiquitous reduction in AR levels (see above), the levels of the same hormones are normal in the SPARKI suggesting normal androgen responsiveness of the hypothalamic-pituitary feedback system. The testis weight of the SPARKI is decreased to $67 \%$ of wild-type and the ventral prostate and seminal vesicles are also reduced in size (to 54 and $55 \%$ respectively), implying a role of selective AREs in the androgen control of these tissues. The reduction in testis weight can largely be accounted for by a reduction in the number of Sertoli cells (to 68\%) but there is also a limited decrease in the ability of these Sertoli cells to support germ cell maturation. In fact, the number of spermatogonia and spermatocytes per Sertoli cell is normal but the number of round and elongated spermatids per Sertoli cell is reduced to 71 and $68 \%$ respectively. SPARKI males display normal mounting behaviour and remain fertile but both the number of litters produced and the size of these litters are reduced by about $50 \%$. On day 10, the expression of Rhox 5, a typical gene that depends on a selective ARE, is reduced by $95 \%$ whereas the expression of genes that are supposedly controlled by classical AREs (Eppin, PCI) is apparently not, or only marginally, affected. The fact that anabolic effects of androgens and pituitary feedback regulation seem not to be affected in the SPARKI whereas both the testes and the accessory sex tissues are reduced in size, suggests that not only individual genes but also different physiological programs may be affected by targeting either classical or selective AREs. These observations further support the contention that it may be possible to develop selective androgen receptor modulators (SARMS) targeting selective subsets of genes and minimizing unwanted side effects [129].

\section{THE MOLECULAR PATHWAYS BY WHICH ANDRO- GENS CONTROL GERM CELL DEVELOPMENT}

After the establishment of the Sertoli cell as the main target for androgen action in the control of spermatogenesis the main challenge remains to unravel the molecular pathways involved. Since, as already discussed, studies with isolated Sertoli cells or Sertoli cell lines have proven of limited help, recent attempts have focused on the use of in vivo sytems. Such studies have been made possible by the development of a number of powerful experimental models and tools. Mice with a selective ablation of the AR in Sertoli cells certainly represent one of the most interesting experimental paradigms presently available. Essentially two approaches are possible in the search for androgen-regulated genes relevant to spermatogenesis. One possibility is to depart from a process known to be dependent on androgen action (meiosis, spermatid adhesion, sper-

Table 2. Comparison of the Phenotypes of Mouse Strains Expressing Different AR Alleles in A Ubiquitous or A Sertoli Cell-Selective Fashion

\begin{tabular}{|c|c|c|c|c|}
\hline & AR $^{\text {flox }}$ day 50 & SCARKO day 50 & ARKO day 50 & SPARKI day 77 \\
\hline \hline AR allele & Floxed exon 2 & Deletion of exon 2 & Deletion of exon 2 & Substitution of exon 3 by GR exon 4 \\
\hline Expression of mutant allele & ubiquitous & Sertoli cell & ubiquitous & ubiquitous \\
\hline External phenotype & male & male & female & male \\
\hline Development of male reproductive tract & normal & normal & absent & normal \\
\hline Testicular descent & normal & normal & defective & $67 \% *$ \\
\hline Testis weight & $86 \%{ }^{*}$ & $28 \% *$ & $8 \% *$ & $55 \% *$ \\
\hline Seminal vesicle weight & $106 \%$ & $108 \%$ & absent & male \\
\hline Body weight curve & male & male & $143 \% *$ & $113 \%$ \\
\hline Serum LH & $71 \%$ & $178 \%$ & $145 \% *$ & $103 \%$ \\
\hline Serum FSH & $123 \%$ & $97 \% *$ & $43 \% *$ & $68 \% *$ \\
\hline Sertoli cell number & $109 \%$ & $28 \% *$ & $3 \% *$ & $55 \% *$ \\
\hline
\end{tabular}


miation...) and to explore directly which of the genes involved may be subject to androgen regulation. Alternatively, microarray technology can be used to screen genome wide for genes that are affected by the presence/and or activity of androgens in the testis or in Sertoli cells. The latter approach has recently revealed some intriguing properties of the androgen-regulated gene network in the testis and in this overview we will focus on these microarray data.

The first two studies applying microarray technology to the study of androgen action in the testis concentrated on early effects of androgens in either hpg mice or wild-type prepubertal mice [130, 131]. The use of exogenous androgens implies that the observed effects may reflect primary actions in Sertoli cells, Leydig cells or peritubular myoid cells.

In the hpg model early effects of testosterone propionate (TP 25 $\mathrm{mg} \mathrm{sc}$ ) were analyzed in males pretreated or not with TP. Pretreatment consisted of 3 injections of $5 \mathrm{mg}$ TP every other day followed by 14 days without treatment [130]. One of the most intriguing observations was that at all time points earlier than $24 \mathrm{~h}$ after the final TP injection, more mRNAs were reduced in abundance rather than increased. Some of the more intriguing down-regulated transcripts included nuclear protein 220 and matrin 3, encoding nuclear proteins that might play a role in pre-mRNA splicing, and some class 1 major histocompatibility genes including H2-D1. In the upregulated transcripts transient but marked up-regulation was observed at $4 \mathrm{~h}$ for several transcripts encoding major milk proteins (casein- $\alpha,-\beta$ and $-\gamma$ and whey acidic protein). Rhox 5 expression was increased from $8 \mathrm{~h}$ after treatment onwards.

The study on 8-day-old wild-type mice compared early effects (4-16 h after treatment) of TP or DHT $(0.5 \mathrm{mg})$ [131]. No differences were noticed, however, between the effects of the aromatizable androgen $\mathrm{T}$ and its non-aromatizable metabolite DHT. The expression of some 200 genes was found to be modulated 2-fold or more by TP treatment with an approximately equal distribution between up-regulated and down-regulated genes. Comparison with androgen-regulated genes in the hpg model revealed only a few similarities including Rhox 5 and Cyp $17 \alpha 1$ (cytochrome P450 17 $\alpha$ hydroxylase/17, 20-lyase), a Leydig cell gene down-regulated by TP. Among the interesting genes identified was Amotl1 (angiomotin-like 1), a gene that encodes a tight junction protein with conserved coiled-coil and PDZ-binding domains which seems to be upregulated by TP, and StAR, a gene that encodes a carrier that transports cholesterol to the inner mitochondrial membrane and that is down-regulated by TP not only in Leydig cells but also in Sertoli cells.

Two studies have searched for testicular genes that are differentially expressed in mice with a Sertoli cell-selective knockout of the AR compared to control animals and one study has tried to identify tubular and somatic genes differentially expressed in mice with a ubiquitous inactivation of the AR (Tfm) [132-134].

A first study compared testicular gene expression in SCARKO and control male littermates on postnatal day 10 [132]. This time point was selected to avoid confounding effects of differences in testicular (germ) cell composition due to the meiotic block in SCARKO testes. Moreover, on day 10 the AR is clearly present in Sertoli cells of control testes (in line with earlier studies demonstrating expression of Rhox 5 in wild-type testes from day 9 onwards [86]). Statistical analysis of microarray data from five independent samples from SCARKO and control testes revealed differential expression of 692 genes (396 down-regulated in the SCARKO and 296 up-regulated). Only 40 of the identified genes, however, showed a difference in expression of at least 2-fold (28 down-regulated and 12 up-regulated in the SCARKO). Genes down-regulated in the SCARKO supposedly depend on androgen action in Sertoli cells for their normal expression. Interestingly, at least 3 of these genes (Galgt1 ( $\beta$-1,4-Acetylgalactosaminyltransferase), PCI (protein $\mathrm{C}$ inhibitor) and Eppin (a serine protease inhibitor)) were shown to be essential for male fertility by previous knockout or inactivation studies, and for at least 5 of them (Rhox5, Eppin, Gpd1 (Glycerol-3-phosphate dehydrogenase 1), Tubb3 (Tubulin- $\beta 3$ ), Tpd5211 (Tumor protein D52-like) and PCI) there were earlier indications of androgen regulation. Preferential expression in the tubular compartment and sensitivity to treatment with antiandrogens could be confirmed for 9 genes studied by quantitative RT-PCR: Rhox5, Eppin, Galgt1, Drd4 (dopamine receptor 4), Tsx (Testis specific X-linked gene), Gpd1, Tubb3, PCI, Tpd5211. Rhox5 turned out to be the gene displaying the largest difference between SCARKO and control. Functions overrepresented in the 396 downregulated genes included MAPK activity and, perhaps most strikingly, serine-type endopeptidase inhibitor activity with 5 of these inhibitors down-regulated more that 2-fold. Functions overrepresented in the 296 genes up-regulated in the SCARKO included: signal transduction, cell adhesion, $\mathrm{Ca}^{++}$-binding, $\mathrm{Ca}^{++}$-dependent phospholipid binding and IGF binding. A time study (day 8-20) confirmed the observed pattern of differential expression and also indicated that, apart from serine-type endopeptidase inhibitors and cell adhesion molecules, also serine proteases and genes encoding cytoskeletal elements and extracellular matrix components displayed early and important differences in expression; this suggests that tubular restructuring and cell-junction dynamics may be processes targeted by androgens during prepubertal and early pubertal development.

In a second study, transcriptional profiling was performed to search for differentially expressed genes in the $\mathrm{Ar}^{\text {flox(ex1-neo)/Y }}$; AMH-Cre model $[93,133]$. Since, in this case, the floxed males already display partial androgen insensitivity and a hypomorphic phenotype, the study also tried to identify genes specifically or preferentially affected in the testes of hypomorphic animals, genes affected both in hypomorphic mice and in mice with a Sertoli cellselective knockout and genes specifically or preferentially affected in the Sertoli cell-selective knockout. A major difference with the SCARKO study is that microarray analysis was performed at the age of 8 weeks. The expression of 62 transcripts was found to differ by greater than 2 -fold in the testes of AR mutants as compared to wild-type and more transcripts were up-regulated than downregulated. Functions that were predominant in the genes differentially expressed in the mutants related to metabolic processes, signal transduction and proteases. Twelve transcripts were identified that were uniquely affected in the Sertoli cell-selective knockout and 16 were more affected in the cell-selective knockout than in the hypomorph. None of these genes corresponded to those affected more than 2-fold in the SCARKO model. Actually the only common gene picked up in the 2 studies was Rhox 5 (down regulated 18-fold in the SCARKO and 2-fold in the hypomorph and in the $\left.\mathrm{Ar}^{\text {flox(ex1-neo)/Y}} ; \mathrm{AMH}-\mathrm{Cre}\right)$. The lack of common transcriptional changes between the two studies can largely be explained by differences inherent to the models and differences in experimental setup. As discussed earlier the SCARKO model probably represents a more Sertoli cell-selective and a more complete inactivation of the AR. Since spermatogenesis is blocked in meiosis this model provides valuable information on androgen-regulated genes needed to initiate and support meiosis. Potential effects of androgens specifically related to postmeiotic events in germ cell development, however, may go unnoticed. Such effects may be picked up in the Arflox(ex1-neo)/Y; AMH-Cre model since postmeiotic germ cell development is observed there. Furthermore, the decision in the SCARKO study to search for genes differentially expressed on day 10 has the important advantage that it avoids confounding effects on Sertoli cell or somatic cell gene expression by differences in germ cell development between mutant and control. As illustrated for two representative genes in Fig. 2 this may be an important confounding factor. While microarray data suggests a decrease in the differential expression of Rhox 5 and a complete loss of differential expression for PCI on day 20, quantitative RT-PCR shows that this is an artifact caused by the increased contribution of germ cells to the total 

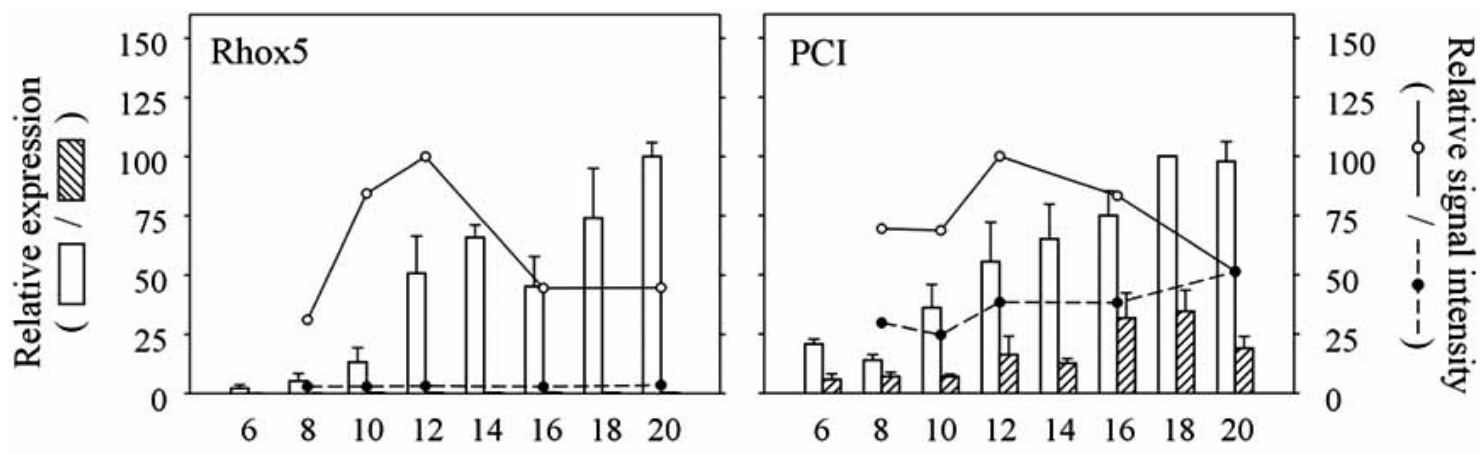

\title{
Control (Q-RT-PCR)

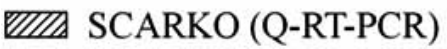

\author{
Control (Microarray) - $\longrightarrow$ \\ SCARKO (Microarray) --•--
}

Fig. (2). Expression patterns of the Rhox5 [128] and the PCI (Protein C Inhibitor) gene between day 6 and 20. Gene expression was assessed by microarray analysis and quantitative RT-PCR (Q-RT-PCR). Left axis [152]: Expression levels measured by Q-RT-PCR in testes of control and SCARKO mice of the indicated ages $(n=3)$. Data were normalized to an external luciferase standard. All values are expressed as a percentage of the highest value measured for the corresponding gene arbitrarily set at 100 . Values represent the mean \pm SEM of 3 measurements. Right axis (lines): Gene expression measured by microarray analysis on a pool of mRNA from 3 testes of 3 control or SCARKO mice of the indicated ages. Data are expressed as a percentage of the highest signal observed for the studied gene arbitrarily set at 100 .

RNA in the control. A drawback of studies on day 10 is of course that Sertoli cells are still immature and proliferating and that some effects of androgens that depend on the presence of more mature germ cells may not be observed. An additional confounding factor inherent to the $\mathrm{Ar}^{\text {flox(ex1-neo)/Y }}$; AMH-Cre model is the 25-fold increase in LH that is already evident in the floxed mice. This increase may explain the observed up-regulation of several known targets of LH signaling in the AR mutants.

A third study compared gene expression in the testes of 20-dayold Tfm and control mice. Initially some 4700 differentially expressed genes were identified most of them of germ cell origin [134]. Subsequent in silico screening and comparison with gene expression data of mice treated with busulphan to cause depletion of germ cells and with $\mathrm{W}^{\mathrm{v}} / \mathrm{W}^{\mathrm{v}}$ mice lacking germ cells because of a mutation in the c-kit receptor, identified 20 genes of a somatic tubular origin that were significantly down-regulated in the Tfm testis and 6 genes that were significantly up-regulated. For nearly all of these genes differential expression was confirmed by quantitative RT-PCR and for 14 of them down-regulated in the Tfm testis, upregulation by androgens could be confirmed in hpg mice treated for 1 week with a testosterone implant. Surprisingly, none of the genes up-regulated in the Tfm was affected by androgen treatment in the $h p g$. Of the total number of genes showing differential expression in the Tfm testis, $50 \%$ were associated with vitamin A metabolism, solute transportation and cytoskeletal function leading the authors to suggest that androgens may affect spermatogenesis by modulating the tubular environment, and by control of retinoic acid metabolism.

Although Rhox 5 is the only differentially expressed gene identified in the 3 AR knockout studies, as well as in the other two transcriptional profiling studies, there may be some other similarities that should be mentioned and that merit further investigation. Several genes related to retinoic acid metabolism were identified in the Tfm model as well as in the hypomorph and the $\mathrm{Ar}^{\text {flox(ex1-neo)/Y }}$; AMH-Cre. Alcohol dehydrogenase 1 (class 1), the rate limiting enzyme in the conversion of vitamin A to the potent signaling molecule retinoic acid, was even found to be upregulated more that 10 -fold in both studies, raising the intriguing possibility of a crosstalk between androgen signaling and the retinoic acid pathway. Examination of the larger lists of genes that are differentially expressed, revealed that 59 genes are down-regulated and 169 are upregulated both in the SCARKO and the Tfm. Only 7 of these genes show a 2 -fold or greater difference in both models. These 7 genes include: Rhox5, Drd4, low density lipoprotein-related protein 4, Tsx and 3 of the serine-type endopeptidase inhibitors: Eppin, Serpina $3 \mathrm{~N}$ and PCI. Cell-adhesion molecules and cytoskeletal elements were also noticed in the three studies. The tight junction component claudin 3, for instance, was found to be specifically down-regulated in the $\mathrm{Ar}^{\text {flox(ex1-neo)/Y}} ; \mathrm{AMH}-\mathrm{Cre}$ and was also downregulated in the SCARKO from the age of 14 days onwards. Its down-regulation correlates with disturbance of formation of the blood-testis barrier observed in the $\mathrm{Ar}^{\text {flox }(\mathrm{ex} 1-\mathrm{neo}) / \mathrm{Y}}$; AMH-Cre [135]. This barrier is also disturbed in the Tfm [136] and the specific contribution of the Sertoli cell and claudin 3 to this disturbance warrants further investigation.

\section{MAIN CONCLUSIONS FROM THE AVAILABLE GENE PROFILING STUDIES}

While transcriptional profiling studies on intact testis tissue avoid the loss of differentiated function and androgen responsiveness observed in isolated and cultured Sertoli cells, they are obviously subject to a number of inherent limitations: the cellular origin of differentially expressed transcripts is not immediately evident; differences in cellular composition between experimental samples and controls may confound the interpretation of the data, and for transcripts that are expressed in different cell types, changes in expression in one cell type may go unnoticed by the absence of such changes or by opposite changes in the other cell types. There is obviously a need for a more detailed analysis of the existing data and for careful additional work. Nonetheless, and despite the poor level of correspondence between the available data, some tentative conclusions may be appropriate.

1) All studies, even those looking at very early effects (4-24 h), identify relatively large sets of genes that may be regulated either directly or indirectly by androgens in the testis. This suggests that androgens may affect an entire spectrum of genes rather than a few key genes. In most of the available data sets the cells responsible for the expression of the alleged androgen target genes have only tentatively been identified. Moreover, the number of genes for which differential expression has been confirmed by an alternative technique such as quantitative RTPCR remains limited. Finally it remains to be defined which genes are primary and which genes are secondary response genes.

2) The fact that Rhox5, a gene known to be induced up to 50-fold by direct interaction with the activated AR in Sertoli cells, is 
identified in all the reported studies, despite the widely different experimental approaches used, proves that all these studies have the power to identify strongly regulated androgen target genes in Sertoli cells. As a consequence, the finding that there is not a single other gene that is consistently picked up in the same studies may indicate either that Rhox 5 is the only gene displaying such an important degree of regulation, or that other strongly regulated genes are expressed only transiently or that relevant genes may not be included in routinely available microarrays. The prominent presence of Rhox 5 in all studies makes it surprising that disruption of Rhox 5 has only limited effects on germ cell development and fertility. This may in part be explained by the recent finding that Rhox 5 is a member of a class of at least 12 homeobox genes and, accordingly, that a loss in function of Rhox 5 may be partially compensated for by some of the other members of the Rhox family [84]. Further studies on these Rhox genes and their orthologs in other species are obviously required.

3) Given the widely different experimental approaches and their specific advantages and limitations, the resulting data should be regarded as complementary rather than as contradictory. Keeping all the mentioned restrictions in mind, it cannot be ignored that the summarized studies have greatly expanded the pool of putative testicular androgen target genes and provide a firm basis for hypothesis-driven research. Along these lines it is important to note that some genes and functions are overrepresented or at least prominently present in the available sets of data.

We already mentioned that 2 studies identified several genes related to vitamin A metabolism suggesting a link between androgen action and retinoic acid metabolism. Such a link might be highly relevant given the increasing evidence for a role of retinoic acid in the control of meiosis $[137,138]$. Interestingly, both studies involved animals with a ubiquitous (complete or partial) form of androgen insensitivity, suggesting that Sertoli cells might not be the main or the only cell involved.

Other gene products found to be markedly modulated by androgen action in several of the summarized studies are proteases and protease inhibitors, cell adhesion molecules and cytoskeletal elements, suggesting that tubular restructuring (related to pubertal development and/or germ cell migration) and cell junction dynamics may be important targets for androgen action. By controlling tubular restructuring and cell junction dynamics as well as cell metabolism and important carriers involved in solute transportation, functions that are also prominently present in several studies, androgens may play a key role in the creation of an environment that is permissive for germ cell development.

4) The available list of putative target genes offers a basis to screen for genes that are also androgen regulated in other models and species and in this way to develop tools to study disturbed androgen action in experimental animals and in man. Androgen-regulated genes identified in the SCARKO model, for example, have proven useful to guide searches in the SPARKI model for genes that depend on selective or classical AREs [128].

\section{GENERAL CONCLUSIONS AND PERSPECTIVES FOR MALE CONTRACEPTION}

The development of novel transgenic models and the introduction of transcriptional profiling have allowed considerable progress in our understanding of androgen action in the testis. Sertoli cellselective knockout models show unambiguously that the Sertoli cell is the key target for androgen action in the control of spermatogenesis. An intriguing but essential property of the Sertoli cell is that its androgen responsiveness, as well as the nature of its responses, is variable and markedly influenced by its microenvironment and its interactions with neighboring peritubular and germ cells. Comparison of mice with ubiquitous and Sertoli cell-selective knockouts of the AR as well as studies in mice with a peritubular cell AR knockout indicate that peritubular myoid cells contribute to some specific effects of androgens on Sertoli cells and spermatogenesis. The nature of the signaling pathways involved remains largely elusive. Mice with a complete and selective knockout of the AR in Sertoli cells show that progress through meiosis is critically dependent on activation of the AR in Sertoli cells. There are several indications that meiosis requires lower concentrations of androgens than subsequent steps in the spermatogenic cascade and, accordingly, identification of androgen-dependent genes controlling progression through meiosis is central to our understanding of the regulation and molecular basis of androgen-driven induction of spermatogenesis. The finding that higher levels of androgen stimulation may be needed for some postmeiotic steps in germ cell development leaves the possibility that other androgen-induced mediators and/or alternative signaling pathways may be involved.

A few mouse models have been developed mimicking human diseases in which mutations of the AR cause disturbed fertility without affecting male sexual development. Male mice expressing an AR with an expanded CAG/polyglutamine repeat display a progressive form of subfertility comparable to that observed in SBMA and offer a paradigm to study the mechanisms by which this AR polyglutamine tract results in toxicity in Sertoli cells. The SPARKI mouse shows that androgen-responsive genes can be differentially targeted depending on the nature (classical or selective) of their AREs. Selective AREs are apparently not essential for the anabolic effects of androgens and pituitary feedback but are important for their reproductive functions and more particularly for the numerical and functional development of Sertoli cells and for fertility. The model suggests that it should be possible to target particular subsets of genes (e.g. related to fertility) while minimizing effects on other subsets.

Transcriptional profiling studies in mice with Sertoli cellselective AR ablation, and in a number of other experimental paradigms, have tried to identify androgen-regulated genes relevant to the control of spermatogenesis. In all studies, relatively large numbers of genes, rather than a few key genes, seem to be affected by androgen action although the number of genes affected 2-fold or more is more limited. Nonetheless, apart from Rhox5, there is little overlap in the lists of genes that have tentatively been identified as androgen regulated and/or expressed in Sertoli cells. This may be due largely to dissimilarities in experimental setup and to inherent differences in the experimental paradigms used for gene identification. There is an obvious need for a critical appraisal of the genes presently identified and for further studies. Genes related to tubular restructuring, cell junction dynamics, cytoskeleton, solute transportation and vitamin A metabolism are prominently present in the available data sets. All these processes have been shown to be amenable to pharmacologic interference and/or to be targets for toxic effects on spermatogenesis [139-141]. It is obvious, however, that more work is needed to identify androgen-dependent target genes that could serve as a suitable base for novel forms of male contraception. Ideal targets should: 1) be expressed and exert critical functions (also) in the adult human testis; 2) be amenable to testing in animals; 3) not produce adverse effects other than male infertility when inactivated. Testis-specific target genes expressed in Sertoli cells, rather than in germ cells, have an obvious attraction since they may avoid the need to pass through the blood-testis barrier. Interference with androgen target genes playing a key role in the control of spermatogenesis (rather than with androgen production itself, as in current contraceptive regimens) would offer the important advantage that it avoids the need for androgen administration with all the inherent problems of reaching optimal concentrations and a correct balance between androgens and their metabolites. One of the important lessons from the mice models with a Sertoli cellselective knockout of the AR may be that they show that it is possible to interfere with androgen signaling and to block spermatogene- 
sis completely without causing a massive breakdown of testicular architecture or major inflammatory reactions.

In conclusion: although further work needs to be done, it may reasonably be anticipated that continued efforts to identify androgen-regulated genes in the testis will result in the identification of subsets of genes that can be used for diagnostic purposes and in the identification of targets for the development of novel male contraceptives.

\section{ACKNOWLEDGEMENT}

The work described from authors laboratory was supported by a Concerted Research Action (Research Fund, Katholieke Universiteit Leuven) and by a research grant and a postdoctoral fellowship to K.D.G. from the Fund for Scientific Research Flanders (Belgium).

\section{REFERENCES}

[1] Weinbauer, G.F.; Nieschlag, E. In Molecular Biology of the male reproductive system; de Kretser, Ed.; Academic Press: New York, 1993; pp. 99-142.

[2] Sharpe, R.M. In The Physiology of Reproduction; Knobil; Neill, Eds.; Raven Press: New York, 1994; pp. 1363-1434.

[3] McLachlan, R.I.; O'Donnell, L.; Meachem, S.J.; Stanton, P.G.; de Kretser, D.M.; Pratis, K.; Robertson, D.M. Recent Prog. Horm. Res., 2002, 57, 149.

[4] Amory, J.K.; Page, S.T.; Bremner, W.J. Nat. Clin. Pract. Endocrinol. Metab., 2006, 2,32

[5] Wenk, M.; Nieschlag, E. Eur. J. Contracept. Reprod. Health Care, 2006, 11, 69

[6] Wu, F.C.W. Mol. Cell. Endocrinol., 2006, 250, 2

[7] Plant, T.M.; Marshall, G.R. Endocr. Rev., 2001, 22, 764

[8] Walker, W.H.; Cheng, J. Reproduction, 2005, 130, 15

[9] Orth, J.M. Endocrinology, 1984, 115, 1248.

[10] Russell, L.D.; Peterson, R.N. J. Reprod. Fertil., 1984, 70, 635

[11] Haywood, M.; Spaliviero, J.; Jimemez, M.; King, N.J.C.; Handelsman, D.J.; Allan, C.M. Endocrinology, 2003, 144, 509.

[12] Matthiesson, K.L.; McLachlan, R.I.; O'Donnell, L.; Frydenberg, M.; Robertson, D.M.; Stanton, P.G.; Meachem, S.J. J. Clin. Endocrinol. Metab., 2006, 91, 3962 .

[13] Meachem, S.J.; Stanton, P.G.; Schlatt, S. Biol. Reprod., 2005, 72, 1187.

[14] Smith, P.E.; Engle, E.T. Am. J. Anat, 1927, 40, 159

[15] Greep, R.O.; Fevold, H.L.; Hisaw, F.L. Anat. Rec., 1937, 65, 261

[16] Nelson, W.O.; Merckel, C.E. Proc. Soc. Exp. Biol. Med, 1938, 38, 737.

[17] Smith, P.E. Yale J. Biol. Med., 1944, 17, 283.

[18] Handelsman, D.J.; Spaliviero, J.A.; Simpson, J.M.; Allan, C.M.; Singh, J. Endocrinology, 1999, 140, 3938.

[19] Singh, J.; Oneill, C.; Handelsman, D.J. Endocrinology, 1995, 136, 5311

[20] Tapanainen, J.S.; Aittomaki, K.; Min, J.; Vaskivuo, T.; Huhtaniemi, I.T. Nat. Genet., 1997, 15, 205.

[21] Dierich, A.; Sairam, M.R.; Monaco, L.; Fimia, G.M.; Gansmuller, A.; LeMeur, M.; Sassone-Corsi, P. Proc. Natl. Acad. Sci. U. S. A., 1998, 95, 13612

[22] Abel, M.H.; Wootton, A.N.; Wilkins, V.; Huhtaniemi, I.; Knight, P.G.; Charlton, H.M. Endocrinology, 2000, 141, 1795

[23] Kumar, T.R.; Wang, Y.; Lu, N.F.; Matzuk, M.M. Nat. Genet., 1997, 15, 201

[24] Kerr, J.B.; Millar, M.; Maddocks, S.; Sharpe, R.M. Anat. Rec., 1993, 235 , 547.

[25] Ghosh, S.; Bartke, A.; Grasso, P.; Reichert, L.E.; Russell, L.D. Endocrinology, 1992, 131, 485 .

[26] Franca, L.R.; Parreira, G.G.; Gates, R.J.; Russell, L.D. J. Androl., 1998, 19, 335.

[27] Parvinen, M. Endocr. Rev., 1982, 3, 404

[28] Bremner, W.J.; Millar, M.R.; Sharpe, R.M.; Saunders, P.T.K. Endocrinology, 1994, $135,1227$.

[29] Cameron, D.F.; Muffly, K.E.; Nazian, S.J. Proc. Soc. Exp. Biol. Med., 1993, $202,457$.

[30] O'Donnell, L.; Stanton, P.G.; Bartles, J.R.; Robertson, D.M. Biol. Reprod., 2000, 63, 99 .

[31] O'Donnell, L.; McLachlan, R.I.; Wreford, N.G.; deKretser, D.M.; Robertson, D.M. Biol. Reprod., 1996, 55, 895.

[32] Zhang, J.Y.; Wong, C.H.; Xia, W.L.; Mruk, D.D.; Lee, N.P.Y.; Lee, W.M.; Cheng, C.Y. Endocrinology, 2005, 146, 1268 .

[33] Wong, C.H.; Xia, W.L.; Lee, N.P.Y.; Mruk, D.D.; Lee, W.M.; Cheng, C.Y. Endocrinology, 2005, 146, 1192.

[34] Saito, K.; O'Donnell, L.; McLachlan, R.I.; Robertson, D.M. Endocrinology, 2000, 141, 2779

[35] Beardsley, A.; O'Donnell, L. Biol. Reprod., 2003, 68, 1299.

[36] Meistrich, M.L.; Shetty, G. Int. J. Androl., 2003, 26, 141.

[37] Shetty, G.; Weng, C.C.Y.; Porter, K.L.; Zhang, Z.; Pakarinen, P.; Kumar, T.R.; Meistrich, M.L. Endocrinology, 2006, 147, 3563.

[38] Quigley, C.A.; Debellis, A.; Marschke, K.B.; Elawady, M.K.; Wilson, E.M.; French, F.S. Endocr. Rev., 1995, 16, 271.

[39] Gao, W.Q.; Bohl, C.E.; Dalton, J.T. Chem. Rev., 2005, 105, 3352
[40] Mhatre, A N - Trifiro, M.A - Kaufman, M- Kazemiesfarjani, P.; Figlewicz, D.; Rouleau, G.; Pinsky, L. Nat. Genet., 1993, 5, 184.

[41] Chamberlain, N.L.; Driver, E.D.; Miesfeld, R.L. Nucleic Acids Res., 1994, 22,3181 .

[42] Ochsenkuhn, R.; de Kretser, D.M. Int. J. Androl., 2003, 26, 195

[43] La Spada, A.R.; Wilson, E.M.; Lubahn, D.B.; Harding, A.E.; Fischbeck, K.H. Nature, 1991, 352, 77.

[44] Stenoien, D.L.; Cummings, C.J.; Adams, H.P.; Mancini, M.G.; Patel, K.; DeMartino, G.N.; Marcelli, M.; Weigel, N.L.; Mancini, M.A. Hum. Mol. Genet., 1999, 8, 731 .

[45] Blok, L.J.; deRuiter, P.E.; Brinkmann, A.O. Endocr. Res., 1996, 22, 197.

[46] Tyagi, R.K.; Lavrovsky, Y.; Ahn, S.C.; Song, C.S.; Chatterjee, B.; Roy, A.K. Mol. Endocrinol., 2000, 14, 1162.

[47] Verrijdt, G.; Haelens, A.; Claessens, F. Mol. Genet. Metab., 2003, 78, 175

[48] Chang, C.Y.; McDonnell, D.P. Trends Pharmacol. Sci., 2005, 26, 225.

[49] McKenna, N.J.; Lanz, R.B.; O'Malley, B.W. Endocr. Rev., 1999, $20,321$.

[50] Gehin, M.; Mark, M.; Dennefeld, C.; Dierich, A.; Gronemeyer, H.; Chambon, P. Mol. Cell. Biol., 2002, 22, 5923.

[51] Ye, X.C.; Han, S.J.; Tsai, S.Y.; Demayo, F.J.; Xu, J.M.; Tsai, M.J.; O'Malley, B.W. Proc. Natl. Acad. Sci. U. S. A., 2005, 102, 9487.

[52] Wilson, J.D. In Handbook of Physiology, Section 7, volume V, Endocrinology; Hamilton; Greep, Eds.; Williams \&Wilkins Co: Baltimore, Maryland, 1975; pp. 143-172.

[53] Wilson, J.D. Prostate, 1996, 88

[54] Russell, D.W.; Wilson, J.D. Annu. Rev. Biochem., 1994, 63, 25

[55] Wilson, J.D.; Griffin, J.E.; Russell, D.W. Endocr. Rev., 1993, 14, 577.

[56] Nilsson, S.; Gustafsson, J.A. Crit. Rev. Biochem. Mol. Biol., 2002, 37, 1.

[57] O'Donnell, L.; Robertson, K.M.; Jones, M.E.; Simpson, E.R. Endocr. Rev. 2001, 22, 289.

[58] Walker, W.H. Curr. Top. Dev. Biol., 2003, 56, 25.

[59] Gorczynska, E.; Handelsman, D.J. Endocrinology, 1995, 136, 2052

[60] Fix, C.; Jordan, C.; Cano, P.; Walker, W.H. Proc. Natl. Acad. Sci. U. S. A. 2004, 101, 10919.

[61] Cheng, J.; Watkins, S.C.; Walker, W.H. Endocrinology, 2007, 148, 2066.

[62] Sharpe, R.M. In Sertoli Cell Biology; Skinner; Griswold, Eds.; Elsevier Academic Press: San Diego, 2006; pp. 199-216.

[63] Merlet, J.; Racine, C.; Moreau, E.; Moreno, S.G.; Habert, R. Proc. Natl. Acad. Sci. U. S. A., 2007, 104, 3615.

[64] Grootegoed, J.A.; Peters, M.J.; Mulder, E.; Rommerts, F.F.G.; Vandermolen, H.J. Mol. Cell. Endocrinol., 1977, 9, 159.

[65] Lyon, M.F.; Glenister, P.H.; Lamoreux, M.L. Nature, 1975, 258, 620

[66] Johnston, D.S.; Russell, L.D.; Friel, P.J.; Griswold, M.D. Endocrinology, 2001, 142, 2405 .

[67] Tsai, M.Y.; Yeh, S.D.; Wang, R.S.; Yeh, S.; Zhang, C.; Lin, H.Y.; Tzeng, C.R.; Chang, C. Proc. Natl. Acad. Sci. U. S. A., 2006, 103, 18975.

[68] De Gendt, K.; Swinnen, J.V.; Saunders, P.T.K.; Schoonjans, L.; Dewerchin, M.; Devos, A.; Tan, K.; Atanassova, N.; Claessens, F.; Lecureuil, C.; Heyns, W.; Carmeliet, P.; Guillou, F.; Sharpe, R.M.; Verhoeven, G. Proc. Natl. Acad. Sci. U. S. A., 2004, 101, 1327.

[69] Nakhla, A.M.; Mather, J.P.; Janne, O.A.; Bardin, C.W. Endocrinology, 1984, $115,121$.

[70] Verhoeven, G. Verhandelingen van de Koninklijke Academie voor Geneeskunde van België, 1992, 54, 299.

[71] Verhoeven, G.; Cailleau, J. Endocrinology, 1988, 122, 1541.

[72] Perez-Infante, V.; Bardin, C.W.; Gunsalus, G.L.; Musto, N.A.; Rich, K.A.; Mather, J.P. Endocrinology, 1986, 118, 383.

[73] Huggenvik, J.I.; Idzerda, R.L.; Haywood, L.; Lee, D.C.; Mcknight, G.S.; Griswold, M.D. Endocrinology, 1987, 120, 332

[74] Verhoeven, G.; Cailleau, J. Mol. Cell. Endocrinol., 1988, 57, 61.

[75] Skinner, M.K.; Fritz, I.B. Proc. Natl. Acad. Sci. U. S. A., 1985, 82, 114.

[76] Skinner, M.K.; Fetterolf, P.M.; Anthony, C.T. J. Biol. Chem., 1988, 263 2884

[77] Verhoeven, G.; Cailleau, J. Endocrinology, 1988, 123, 2100

[78] Swinnen, K.; Cailleau, J.; Heyns, W.; Verhoeven, G. Endocrinology, 1990, $126,142$.

[79] Cheng, C.Y.; Mather, J.P.; Byer, A.L.; Bardin, C.W. Endocrinology, 1986 118,480 .

[80] Roberts, K.; Griswold, M.D. Endocrinology, 1989, 125, 1174.

[81] Sharpe, R.M.; Maddocks, S.; Millar, M.; Kerr, J.B.; Saunders, P.T.K.; Mckinnell, C. J. Androl., 1992, 13, 172.

[82] Roberts, K.P. In Sertoli cell biology; Skinner; Griswold, Eds.; Elsevier, Academic Press: San Diego, 2005; pp. 329-342.

[83] Day, A.R.; Lee, A.S. DNA, 1989, 8, 301

[84] MacLean, J.A.; Chen, M.G.A.; Wayne, C.M.; Bruce, S.R.; Rao, M.; Meistrich, M.L.; Macleod, C.; Wilkinson, M.F. Cell, 2005, 120, 369.

[85] Sneddon, S.F.; Walther, N.; Saunders, P.T.K. Endocrinology, 2005, 146 , 5304.

[86] Lindsey, J.S.; Wilkinson, M.F. Dev. Biol., 1996, 179, 471.

[87] Sutton, K.A.; Maiti, S.; Tribley, W.A.; Lindsey, J.S.; Meistrich, M.L.; Bucana, C.D.; Sanborn, B.M.; Joseph, D.R.; Griswold, M.D.; Cornwall, G.A Wilkinson, M.F. J. Androl., 1998, 19, 21.

[88] Ku, C.Y.; Loosemitchell, D.S.; Sanborn, B.M. Biol. Reprod., 1994, 51, 319.

[89] Denolet, E.; De Gendt, K.; Swinnen, J.V.; Verrijdt, G.; Deboel, L.; Roskams, T.; Verhoeven, G. J. Steroid Biochem. Mol. Biol., 2006, 98, 164.

[90] Verhoeven, G.; Hoeben, E.; De Gendt, K. Andrologia, 2000, 32, 42. 
[91] Jegou, B. International Review of Cytology - A Survey of Cell Biology, 1993, $147,25$.

[92] Sauer, B. Guide to Techniques in Mouse Development, 1993, 225, 890.

[93] Holdcraft, R.W.; Braun, R.E. Development, 2004, 131, 459.

[94] Chang, C.S.; Chen, Y.T.; Yeh, S.D.; Xu, Q.Q.; Wang, R.S.; Guillou, F.; Lardy, H.; Yeh, S.Y. Proc. Natl. Acad. Sci. U. S. A., 2004, 101, 6876.

[95] Hellwinkel, O.J.C.; Bull, K.; Holterhus, P.M.; Homburg, N.; Struve, D.; Hiort, O. J. Steroid Biochem. Mol. Biol., 1999, 68, 1.

[96] Lecureuil, C.; Fontaine, I.; Crepieux, P.; Guillou, F. Genesis, 2002, 33, 114.

[97] Lallemand, Y.; Luria, V.; Haffner-Krausz, R.; Lonai, P. Transgenic Res., 1998, 7, 105 .

[98] O'Shaughnessy, P.J.; Johnston, H.; Willerton, L.; Baker, P.J. J. Cell Sci., 2002, 115, 3491 .

[99] He, W.W.; Kumar, M.V.; Tindall, D.J. Nucleic Acids Res., 1991, 19, 2373.

[100] Matsumoto, T.; Takeyama, K.I.; Sato, T.; Kato, S. J. Steroid Biochem. Mol. Biol., 2003, 85, 95 .

[101] Yeh, S.Y.; Tsai, M.Y.; Xu, Q.Q.; Mu, X.M.; Lardy, H.; Huang, K.E.; Lin, H.; Yeh, S.D.; Altuwaijri, S.; Zhou, X.C.; Xing, L.P.; Boyce, B.F.; Hung, M.C.; Zhang, S.; Gan, L.; Chang, C.S. Proc. Natl. Acad. Sci. U. S. A., 2002, 99, 13498.

[102] Notini, A.J.; Davey, R.A.; McManus, J.F.; Bate, K.L.; Zajac, J.D. J. Mol. Endocrinol., 2005, 35, 547

[103] Tan, K.A.L.; De Gendt, K.; Atanassova, N.; Walker, M.; Sharpe, R.M.; Saunders, P.T.K.; Denolet, E.; Verhoeven, G. Endocrinology, 2005, 146, 2674.

[104] Johnston, H.; Baker, P.J.; Abel, M.; Charlton, H.M.; Jackson, G.; Fleming, L.; Kumar, T.R.; O'Shaughnessy, P.J. Endocrinology, 2004, 145, 318.

[105] Scott, H.M.; Hutchison, G.R.; Mahood, I.K.; Hallmark, N.; Welsh, M.; De Gendt, K.; Verhoeven, G.; O'Shaughnessy, P.; Sharpe, R.M. Endocrinology, 2007, 148, 2027.

[106] Sharpe, R.M.; Kerr, J.B.; Mckinnell, C.; Millar, M. J. Reprod. Fertil., 1994, 101,193 .

[107] De Gendt, K.; Atanassova, N.; Tan, K.A.L.; de Franca, L.R.; Parreira, G.G.; Mckinnell, C.; Sharpe, R.M.; Saunders, P.T.K.; Mason, J.I.; Hartung, S.; Ivell, R.; Denolet, E.; Verhoeven, G. Endocrinology, 2005, 146, 4117.

[108] Ma, X.P.; Dong, Y.L.; Matzuk, M.M.; Kumar, T.R. Proc. Natl. Acad. Sci. U. S. A., 2004, 101, 17294.

[109] Zhang, F.P.; Poutanen, M.; Wilbertz, J.; Huhtaniemi, I. Mol. Endocrinol., 2001, 15,172

[110] Lei, Z.M.; Mishra, S.; Zou, W.; Xu, B.; Foltz, M.; Li, X.; Rao, C.V. Mol. Endocrinol., 2001, 15, 184

[111] Lei, Z.M.; Mishra, S.; Ponnuru, P.; Li, X.; Yang, Z.W.; Ra, C.V. Biol. Reprod., 2004, 71, 1605.

[112] Steinberger, E. Physiol. Rev., 1971, 51, 1.

[113] Steinberger, E.; Duckett, G.E. J. Reprod. Fertil., 1967, Suppl.2, 75

[114] Kalra, S.P.; Prasad, M.R.N. Endocrinology, 1967, 81, 965.

[115] Cailleau, J.; Heyns, W.; Verhoeven, G. J. Steroid Biochem., 1984, 21, 691

[116] Zhang, C.X.; Yeh, S.Y.; Chen, Y.T.; Wu, C.C.; Chuang, K.H.; Lin, H.Y.; Wang, R.S.; Chang, Y.J.; Mendis-Handagama, C.; Hu, L.Q.; Lardy, H.; Chang, C.S. Proc. Natl. Acad. Sci. U. S. A., 2006, 103, 17718.

[117] Holtwick, R.; Gotthardt, M.; Skryabin, B.; Steinmetz, M.; Potthast, R.; Zetsche, B.; Hammer, R.E.; Herz, J.; Kuhn, M. Proc. Natl. Acad. Sci. U. S. A., 2002, 99, 7142 .

[118] Hardy, M.P.; Kelce, W.R.; Klinefelter, G.R.; Ewing, L.L. Endocrinology, 1990, 127,488 .

[119] Verhoeven, G.; Cailleau, J. Mol. Cell. Endocrinol., 1990, 71, 239.

[120] Boujrad, N.; Ogwuegbu, S.O.; Garnier, M.; Lee, C.H.; Martin, B.M.; Papadopoulos, V. Science, 1995, 268, 1609.

[121] Krishnamurthy, H.; Kats, R.; Danilovich, N.; Sairam, M.R. Biol. Reprod., 2001, 64, 208

[122] Baker, P.J.; Pakarinen, P.; Huhtaniemi, I.T.; Abel, M.H.; Charlton, H.M.; Kumar, T.R.; O'Shaughnessy, P.J. Endocrinology, 2003, 144, 138.
[123] Fynn-Thompson, E.; Cheng, H.; Teixeira, J. Mol. Cell. Endocrinol., 2003, $211,99$.

[124] Salva, A.; Hardy, M.P.; Wu, X.F.; Sottas, C.M.; MacLaughlin, D.T.; Donahoe, P.K.; Lee, M.M. Biol. Reprod., 2004, 70, 600.

[125] Gnessi, L.; Basciani, S.; Mariani, S.; Arizzi, M.; Spera, G.; Wang, C.Y.; Bondjers, C.; Karlsson, L.; Betsholtz, C. J. Cell Biol., 2000, 149, 1019.

[126] McManamny, P.; Chy, H.S.; Finkelstein, D.I.; Craythorn, R.G.; Crack, P.J.; Kola, I.; Cheema, S.S.; Horne, M.K.; Wreford, N.G.; O'Bryan, M.K.; de Kretser, D.M.; Morrison, J.R. Hum. Mol. Genet., 2002, 11, 2103.

[127] Yu, Z.G.; Dadgar, N.; Albertelli, M.; Scheller, A.; Albin, R.L.; Robins, D.M.; Lieberman, A.P. Am. J. Pathol., 2006, 168, 195.

[128] Schauwaers, K.; De Gendt, K.; Saunders, P.T.K.; Atanassova, N.; Haelens, A.; Callewaert, L.; Moehren, U.; Swinnen, J.V.; Verhoeven, G.; Verrijdt, G.; Claessens, F. Proc. Natl. Acad. Sci. U. S. A., 2007, 104, 4961.

[129] Chen, J.Y.; Hwang, D.J.; Bohl, C.E.; Miller, D.D.; Dalton, J.T. J. Pharmacol. Exp. Ther., 2005, 312, 546.

[130] Sadate-Ngatchou, P.I.; Pouchnik, D.J.; Griswold, M.D. Mol. Endocrinol., 2004, 18, 422 .

[131] Zhou, Q.; Shima, J.E.; Nie, R.; Friel, P.J.; Griswold, M.D. Biol. Reprod., 2005, 72, 1010.

[132] Denolet, E.; De Gendt, K.; Allemeersch, J.; Engelen, K.; Marchal, K.; Van Hummelen, P.; Tan, K.A.L.; Sharpe, R.M.; Saunders, P.T.K.; Swinnen, J.V.; Verhoeven, G. Mol. Endocrinol., 2006, 20, 321.

[133] Eacker, S.M.; Shima, J.E.; Connolly, C.M.; Sharma, M.; Holdcraft, R.W ; Griswold, M.D.; Braun, R.E. Mol. Endocrinol., 2007, 21, 895.

[134] O'Shaughnessy, P.J.; Abel, M.; Charlton, H.M.; Hu, B.; Johnston, H.; Baker, P.J. Endocrinology, 2007, 148, 2914

[135] Meng, J.; Holdcraft, R.W.; Shima, J.E.; Griswold, M.D.; Braun, R.E. Proc Natl. Acad. Sci. U. S. A., 2005, 102, 16696.

[136] Fritz, I.B.; Lyon, M.F.; Setchell, B.P. J. Reprod. Fertil., 1983, 67, 359.

[137] Koubova, J.; Menke, D.B.; Zhou, Q.; Capel, B.; Griswold, M.D.; Page, D.C. Proc. Natl. Acad. Sci. U. S. A., 2006, 103, 2474.

[138] Wolgemuth, D.J. Nat. Genet., 2006, 38, 1362.

[139] Mruk, D.D.; Wong, C.H.; Silvestrini, B.; Cheng, C.Y. Nat. Med., 2006, 12, 1323.

[140] Chung, S.S.W.; Wolgemuth, D.J. Cytogenetic and Genome Research, 2004 105, 189.

[141] Boekelheide, K.; Johnson, K.J.; Richburg, J.H. In Sertoli Cell Biology; Skinner; Griswold, Eds.; Elsevier, Academic Press: San Diego, 2005; pp. 345-382.

[142] Louis, G.; Fritz, I.B. Mol. Cell. Endocrinol., 1977, 7, 9.

[143] Cheng, C.Y.; Bardin, C.W. Biochemistry (Mosc)., 1986, 25, 5276

[144] Cheng, C.Y.; Bardin, C.W. J. Biol. Chem., 1987, 262, 12768.

[145] Lampa, J.; Hoogerbrugge, J.W.; Baarends, W.M.; Stanton, P.G.; Perryman, K.J.; Grootegoed, J.A.; Robertson, D.M. J. Androl., 1999, 20, 399.

[146] Perryman, K.J.; Stanton, P.G.; Loveland, K.L.; McLachlan, R.I.; Robertson, D.M. Endocrinology, 1996, 137, 3877.

[147] Ailenberg, M.; Mccabe, D.; Fritz, I.B. Endocrinology, 1990, 126, 1561.

[148] Benbrahim-Tallaa, L.; Tabone, E.; Tosser-Klopp, G.; Hatey, F.; Benahmed, M. Biol. Reprod., 2002, 66, 1734.

[149] Magnanti, M.; Giuliani, L.; Gandini, O.; Gazzaniga, P.; Santiemma, V.; Ciotti, M.; Saccani, G.; Frati, L.; Agliano, A.M. J. Steroid Biochem. Mol. Biol., 2000, 74, 149.

[150] Lim, K.; Yoo, J.H.; Kim, K.Y.; Kweon, G.R.; Kwak, S.T.; Hwang, B.D. J. Androl., 1994, 15, 543.

[151] Gye, M.C. Int. J. Androl., 2003, 26, 271

[152] Florin, A.; Maire, M.; Bozec, A.; Hellani, A.; Chater, S.; Bars, R.; Chuzel, F.; Benahmed, M. Endocrinology, 2005, 146, 1532.

[153] Weiner, K.X.B.; Pentecost, B.T.; Dias, J.A. Mol. Endocrinol., 1990, 4, 1249.

[154] Avallet, O.; Vigier, M.; Leduque, P.; Dubois, P.M.; Saez, J.M. Endocrino$\log y, \mathbf{1 9 9 4}, 134,2079$. 